\title{
ANALISIS DATA MAHASISWA MENGGUNAKAN ALGORITMA K-MEANS CLUSTERING SEBAGAI DASAR PELAKSANA PROMOSI
}

\section{Data Analysis of Students using K-Means Clustering Algorithm as a Basis for The Implementation of Promotion}

\author{
Sterry Fleanry Mulaki ${ }^{1)}$, Nina Setiyawati ${ }^{1)}$ dan Agustinus Fritz Wijaya ${ }^{2)}$ \\ 1) Fakultas Teknologi Informasi/Teknik Informatika, Universitas Kristen Satya Wacana \\ 2) Fakultas Teknologi Informasi/Sistem Informasi, Universitas Kristen Satya Wacana
}

Diterima 08 Juni 2018 / Disetujui 31 Juli 2018

\begin{abstract}
The Promotion Bureau of Satya Wacana Christian University's Information Technology Faculty of Engineering undertakes marketing techniques by sending promotional teams randomly for promotion. The Promotion team sent at random may not be able to achieve the expected target. In order to reach the target, the appropriate promotion team placement will get more efficient results. Data already stored at the time of the student registration at Satya Wacana Christian University can be used to create marketing support strategy that can be very useful for the Faculty of Information Technology. Data used in decision support marketing strategy such as data of student origin, study program, and the origin of school that analyzed using K-Means Clustering so that decision making as basis of promotion implementation can be more efficient. The results obtained in the form of information displayed on desktop applications.

Keywords: K-Means Clustering, Promotion, Student Data.
\end{abstract}

\begin{abstract}
ABSTRAK
Biro Promosi Fakultas Teknologi Informasi Universitas Kristen Satya Wacana melakukan teknik pemasaran dengan mengirimkan tim promosi yang secara acak untuk melakukan promosi. Tim Promosi yang dikirim secara acak belum tentu dapat mencapai target yang diharapkan. Agar mencapai target, penempatan tim promosi yang sesuai akan mendapatkan hasil yang lebih efisien. Data yang sudah tersimpan pada saat mahasiswa melakukan registrasi di Universitas Kristen Satya Wacana, dapat dimanfaatkan untuk membuat strategi pendukung pemasaran yang dapat sangat berguna untuk Fakultas Teknologi Informasi tersebut. Data yang dipakai dalam pendukung keputusan strategi pemasaran antara lain data asal mahasiswa, program studi, serta asal sekolah yang dianalisa menggunakan K-Means Clustering sehingga pembuatan keputusan sebagai dasar pelaksanaan promosi bisa lebih efisien. Hasil yang didapat berupa informasi yang ditampilkan pada aplikasi desktop.
\end{abstract}

Kata Kunci: K-Means Clustering, Promosi, Data Mahasiswa.

\section{PENDAHULUAN}

Berdasarkan wawancara dengan ketua Biro Promosi Fakultas Teknologi Informasi Universitas Kristen Satya Wacana selain ketertarikan dari keunggulan sebuah perusahaan atau instansi, hal yang harus dipikirkan juga adalah strategi dalam hal mempromosikan perusahaan atau instansi tersebut, contohnya strategi untuk penempatan berapa orang dalam tim yang akan mempromosikan perusahaan atau instansi tersebut.

Tim promosi yang dikirim belum tentu dapat mencapai target peminat yang diharapkan. Saat Biro Promosi FTI melakukan promosi yang berupa ekspo, berdasarkan wawancara jumlah orang yang akan dikirim untuk melakukan promosi adalah 3 orang. Dimana jumlah orang yang 
dikirim ditentukan secara random dengan jumlah maksimal 3 orang tanpa melihat data mahasiswa yang sudah menjadi mahasiswa di FTI UKSW sehingga seluruh provinsi akan dikirim jumlah anggota promosi yang sama, padahal setiap provinsi memiliki jumlah peminat yang berbeda. Penempatan tim promosi untuk beberapa daerah masih ditentukan secara manual oleh Biro Promosi FTI UKSW, sama halnya dengan penentuan jumlah anggota tim promosi masih dilakukan secara acak tanpa memperhatikan data mahasiswa FTI yang berasal dari daerah tersebut. Hal tersebut menjelaskan bahwa adanya strategi marketing untuk melakukan promosi FTI UKSW itu penting sehingga Biro Promosi bisa lebih efisien saat melakukan promosi terhadap pengiriman jumlah anggota dalam tim promosi disetiap daerah tujuan promosi.

Clustering merupakan suatu metode untuk mencari dan mengelompokkan data yang memiliki kemiripan karakteriktik (similarity) antara satu data dengan data yang lain, serta $k$-means merupakan pengelompokan data kedalam suatu cluster melalui titik yang sudah ditentukan.

Berdasarkan permasalahan tersebut Implementasi Algoritma K-Means Clustering untuk strategi marketing di Fakultas Teknologi Informasi Universitas Kristen Satya Wacana ini dapat memberikan strategi yang efisien sehingga tim promosi FTI UKSW yang dikirim untuk melakukan promosi bisa membawa peminat yang lebih banyak serta meminimalisir pengeluaran biaya terhadap tim promosi yang dikirim melalui pengelompokan data yang diolah dari data mahasiswa yang sudah menjadi mahasiswa di FTI UKSW.

*Korespondensi Penulis:

E-mail: nina.setiyawati@staff.uksw.edu

\section{TINJAUAN PUSKATA}

\section{Penelitian Terdahulu}

\begin{tabular}{lcr}
\multicolumn{1}{c}{ Penelitian } & yang & berjudul \\
Implementasi Algoritma & K-Means \\
Clustering untuk menentukan & Strategi \\
Marketing President University membahas
\end{tabular}

tentang pengimplementasian algoritma $\mathrm{K}$ Means Clustering ini pada data mahasiswa yang sudah lulus dari President University untuk dilihat kota/kabupaten mana yang menghasilkan lulusan terbanyak dan terbaik dengan mengambil beberapa atribut antara lain, Kota/Kabupaten asal, Program Studi serta IPK dari mahasiswa yang sudah lulus untuk strategi marketing dari President University nantinya, pada artikel ini, digunakan excel sebagai aplikasi untuk mengimplementasikan algoritma K-Means Clustering tersebut (Ong, 2013).

Penelitian lain yang berjudul Data Mining menggunakan Algoritma K-Means Clustering untuk menentukan Strategi Promosi Universitas Dian Nuswantoro membahas tentang pengimplementasian algoritma K-Means Clustering untuk strategi marketing di Unversitas Dian Nuswantoro yang menggunakan acuan penelitian yang dijabarkan sebelumnya, yaitu Implementasi Algoritma K-Means Clustering untuk menentukan Strategi Marketing President University. Penelitian ini dilakukan analisis menggunakan RapidMiner. Selain dari implementasi analisis tersebut, penelitian ini dan penelitian sebelumnya menggunakan data mahasiswa yang sudah lulus dengan mengambil 3 atribut yang sama yakni, Kota/Kabupaten, Program Studi serta IPK (Ramadhani, 2013).

\section{Penelaahan Teori}

Berdasarkan penelitian yang pernah dilakukan tentang penerapan algoritma $K$ Means Clustering untuk strategi marketing suatu universitas maka akan dilakukan penelitian yang membahas tentang Analisa Data Mahasiswa Menggunakan Algoritma K-Means Clustering Sebagai Dasar Pelaksanaan Promosi (Studi Kasus: Biro Promosi FTI UKSW), dimana pengelompokan data berdasarkan karakteristik yang sama dalam satu cluster, bisa menghasilkan informasi yang berguna untuk strategi marketing promosi FTI UKSW. Berbeda dengan penelitian terdahulu yang menggunakan data mahasiswa yang sudah lulus serta 3 atribut yang sama, maka dalam penelitian ini peneliti menggunakan data mahasiswa yang 
sudah mendaftar menjadi mahasiswa Fakultas Teknologi Informasi Universitas Kristen Satya Wacana serta menggunakan 3 atribut yang sedikit berbeda yakni Asal Kota/Kabupaten, Program Studi serta Asal sekolah (SMA, SMK/STM, dan SLTA lainnya) yang diproses menggunakan IBM SPSS Statistics sehingga Fakultas Teknologi Informasi Universitas Kristen Satya Wacana dapat membuat strategi marketing yang lebih efisien sebelum mengirimkan tim promosi untuk melakukan promosi.

Data mining adalah suatu proses pencarian korelasi, pola dan tren baru yang berguna dalam media penyimpanan data berukuran besar menggunakan teknologi pengenalan pola seperti teknik-teknik statistik dan matematis. Istilah lain yang sering digunakan antara lain knowledge mining from data, knowledge extraction, data/pattern analysis, data archeology, dan data dredging (Larose, 2005).

Data mining merupakan suatu kegiatan yang meliputi pengumpulan, pemakaian data historis untuk menentukan keteraturan, pola atau hubungan dalam set data berukuran besar. Salah satu tugas utama dari data mining adalah pengelompokan clustering dimana data yang dikelompokkan belum mempunyai contoh kelompok (Santosa, 2007).

Pada dasarnya clustering merupakan suatu metode untuk mencari dan mengelompokkan data yang memiliki kemiripan karakteriktik (similarity) antara satu data dengan data yang lain. Clustering merupakan salah satu metode data mining yang bersifat tanpa arahan (unsupervised), maksudnya metode ini diterapkan tanpa adanya latihan (training) dan tanpa ada guru (teacher) serta tidak memerlukan target output. Dalam data mining ada dua jenis metode clustering yang digunakan dalam pengelompokan data, yaitu hierarchical clustering dan nonhierarchical clustering (Santosa, 2007).

K-means clustering merupakan salah satu metode data clustering non-hirarki yang mengelompokan data dalam bentuk satu atau lebih cluster/kelompok. Data yang memiliki karakteristik yang sama dikelompokan dalam satu cluster/kelompok dan data yang memiliki karakteristik yang berbeda dikelompokan dengan cluster/kelompok yang lain sehingga data yang berada dalam satu cluster/kelompok memiliki tingkat variasi yang kecil (Agusta, 2007).

\section{METODOLOGI PENELITIAN}

\section{Langkah-Langkah Penelitian}

Tahapan penelitian yang digunakan dalam Implementasi Algoritma K-Means Clustering Untuk Strategi Marketing Promosi Fakultas Teknologi Informasi Universitas Kristen Satya Wacana, ditunjukkan pada Gambar 1:

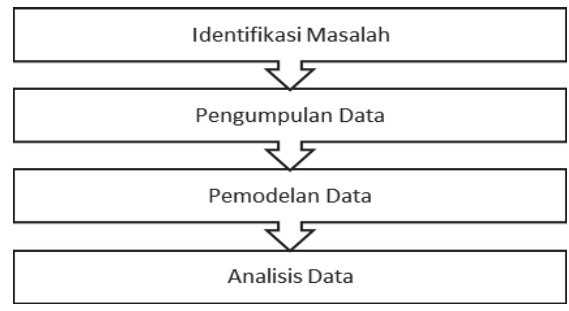

Gambar 1. Tahapan Penelitian

Tahapan penelitian pada Gambar 1 dijelaskan sebagai berikut: tahap 1 adalah identifikasi masalah, berdasarkan hasil wawancara, Biro Promosi FTI UKSW cenderung mengirimkan jumlah anggota tim promosi dengan melihat apakah kegiatan tersebut merupakan kegiatan ekspo atau tidak. Jika kegiatan tersebut ekspo maka dikirim 2-3 orang untuk melakukan promosi, dan ketika kegiatan promosi bukan ekspo maka yang dikirim hanya 1 orang saja. Biro Promosi FTI UKSW mengirimkan tim promosi dengan jumlah anggota secara random tanpa melihat efisiensi dari tindakan tersebut. Pengiriman jumlah tim promosi yang tepat menghasilkan target promosi yang diharapkan, dan membuktikan bahwa kegiatan promosi tersebut efisien. Oleh karena itu penelitian ini dibuat untuk memberikan informasi yang nantinya mendukung strategi marketing, sehingga kegiatan promosi dari Biro Promosi FTI menjadi lebih efisien berdasarkan data yang sudah ada. Tahap 2 adalah pengumpulan 
data, data yang diperlukan dalam penelitian ini diperoleh melalui bagian akademik Universitas Kristen Satya Wacana yang berupa data mahasiswa yang sudah mendaftar ulang pada saat masuk Universitas Kristen Satya Wacana pada tahun 2017 dan data tersebut telah di prepreprocessing sehingga hanya data mahasiswa yang diperlukan saja yang diambil. Data yang diambil antara lain, Nomor Induk Mahasiswa (NIM), Program Studi, Kota Asal, serta Asal sekolah (SMA, SMK/STM). Berikut ini adalah beberapa data mahasiswa yang sudah mendaftar ulang pada Universitas Kristen Satya Wacana yang diurutkan berdasarkan abjad Kota Asal.

Tabel 1. Contoh Data Mahasiswa yang Telah Mendaftar Ulang pada Universitas Kristen Satya Wacana yang Sudah di Pre-

\begin{tabular}{|c|c|c|c|c|}
\hline \multicolumn{5}{|c|}{ processing } \\
\hline $\mathrm{NO}$ & NIM & $\begin{array}{l}\text { Asal } \\
\text { Sekolah }\end{array}$ & Kota Asal & Program Studi \\
\hline 1 & 732017002 & SMA & Kab. Alor & Ilmu Perpustakaan \\
\hline 2 & 672017294 & SMA & $\begin{array}{l}\text { Kab. } \\
\text { Banjarnegara }\end{array}$ & Teknik Informatika \\
\hline 3 & 682017072 & $\begin{array}{l}\text { SLTA } \\
\text { LAIN }\end{array}$ & $\begin{array}{l}\text { Kab. } \\
\text { Banyumas }\end{array}$ & Sistem Informasi \\
\hline 4 & 682017088 & SMA & $\begin{array}{l}\text { Kab. } \\
\text { Banyumas }\end{array}$ & Sistem Informasi \\
\hline 5 & 682017028 & SMK & $\begin{array}{l}\text { Kab. Barito } \\
\text { Selatan }\end{array}$ & Sistem Informasi \\
\hline 6 & 672017701 & SMA & $\begin{array}{l}\text { Kab. Barito } \\
\text { Timur }\end{array}$ & Teknik Informatika \\
\hline 7 & 672017235 & SMA & Kab. Batang & Teknik Informatika \\
\hline 8 & 672017288 & SMA & Kab. Batang & Teknik Informatika \\
\hline 9 & 682017106 & SMK & Kab. Batang & Sistem Informasi \\
\hline 10 & 692017067 & SMA & Kab. Batang & $\begin{array}{l}\text { Desain Komunikasi } \\
\text { Visual }\end{array}$ \\
\hline
\end{tabular}

Tahap 3 adalah pemodelan data, data sebelumnya merupakan data yang belum dapat kita olah karena masih berbentuk karakter, K-Means Clustering merupakan sebuah algoritma yang hanya dapat bekerja saat data yang diolah merupakan data yang berupa bilangan atau integer. Maka, data diatas harus diinisialisasi sehingga bisa dianalisa menggunakan algorima $\mathrm{K}$-Means Clustering. Sebelum langkah inisialisasi adapun proses analisis K-Means Clustering yang dapat kita lihat pada Gambar 2.

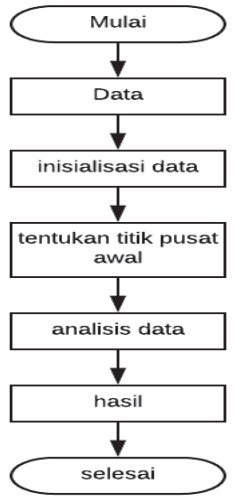

Gambar 2. Flowchart Analisis K-Means

Langkah-langkah yang digunakan saat melakukan inisialisasi antara lain, nilai yang ada di atribut Kota Asal dibuat pembagian wilayah yang menjadi beberapa bagian wilayah, dibagi berdasarkan provinsi dari kabupaten atau kota. Contohnya Sulawesi Utara yang terdiri dari Kota Manado, Kota Tomohon, Kabupaten Minahasa, Kota Bitung, Kabupaten Kepulauan Talaud, Kabupaten Kepulauan Sangihe dan Kabupaten Bolaang Mongondow, kemudian wilayah-wilayah tersebut diurutkan berdasarkan besar frekuensi asal provinsi ke frekuensi yang paling kecil, setelah itu wilayah yang memiliki frekensi paling besar diberikan inisial 1, selanjutnya yang kedua besar diberikan inisial 2, dan seterusnya seperti itu sampai ke wilayah yang mempunyai frekuensi terkecil. Berikut adalah data Kota Asal Mahasiswa yang sudah di inisialisasikan.

Tabel 2. Data Kota Asal Mahasiswa yang Dudah Diinisialisasi

\begin{tabular}{lrr}
\hline Provinsi & Frekuensi & Inisial \\
\hline Jateng & 313 & 1 \\
NTT & 33 & 2 \\
Maluku & 26 & 3 \\
Papua & 24 & 4 \\
Sulut & 20 & 5 \\
... & $\ldots$ & $\ldots$ \\
\hline
\end{tabular}

Setelah menginisialisasi Kota Asal selanjutnya yang harus di inisialiasasi adalah nilai yang ada di atribut Program Studi, seperti pada Tabel 3.

Tabel 3. Inisialisasi Program Studi

\begin{tabular}{lrr}
\hline \multicolumn{1}{c}{ Prodi } & Frekuensi & Inisial \\
\hline Teknik Informatika & 289 & 1 \\
Sistem Informasi & 115 & 2 \\
Desain Komunikasi Visual & 72 & 3 \\
Public Relation & 29 & 4 \\
\hline
\end{tabular}




\begin{tabular}{lcc}
\hline Destinasi Pariwisata & 23 & 5 \\
Pendidikan Teknologi & 21 & 6 \\
Informasi dan Komunikasi & & \\
Ilmu Perpustakaan & 4 & 7 \\
\hline
\end{tabular}

Sama seperti langkah yang dijelaskan pada penginisialisasian Kota asal, program studi yang paling besar frekuensinya mendapatkan inisial 1 , terbesar kedua diinisialisasi 2, dan diinisialkan seterusnya sampai ke frekunsi paling kecil. Selanjutnya inisialisasi asal sekolah (SMA, SMK/STM, atau SMTA lain) yang di lakukan sama seperti menginisialisasi Kota Asal dan Program Studi diatas.

Tabel 4. Inisialisasi Asal Sekolah

\begin{tabular}{lrr}
\hline $\begin{array}{l}\text { Asal } \\
\text { Sekolah }\end{array}$ & Frekuensi & Inisial \\
\hline SMA & 400 & 1 \\
SMK/STM & 129 & 2 \\
SLTA & 22 & 3 \\
Lain & & \\
N/A & 2 & 4 \\
\hline
\end{tabular}

Pada penelitian ini, proses analisis $K$ Means dan hasilnya ditampilkan pada Aplikasi yang dibangun untuk mendukung penelitian ini agar menjadi lebih valid. Aplikasi ini dirancang menggunakan Flowchart terkait sistem yang dibangun.

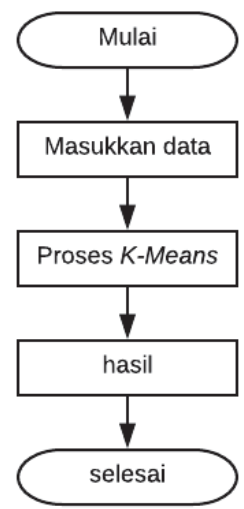

Gambar 3. Flowchart System

Gambar 3 menunjukkan alur sistem yang berjalan dalam sistem yang dibangun untuk menampilkan hasil dari analisa data menggunakan Algoritma K-Means Clustering untuk strategi marketing FTI UKSW. Dimulai dari mengimpor data dalam format xls atau xlsx, setelah itu data yang dimasukan harus diolah terlebih dahulu dengan menginisialisasi data berdasarkan frekuensi (besar ke kecil). Data yang sudah dinisialisasi tersebut diolah menggunakan Algoritma K-Means Clustering sehingga hasil akhir dari analisis data berbentuk laporan yang menunjukkan pengelompokan data yang terbentuk.

\section{HASIL DAN PEMBAHASAN}

Proses analisis K-Means pada data mahasiswa dilakukan setelah inisialisasi. Pada penelitian ini proses inisialisasi sampai interpretasi hasil analisis menggunakan K-Means ditampilkan menggunakan aplikasi berbasis desktop yang dibangun menggunakan bahasa pemrograman Java. Adapun data diimpor dalam format xls atau xlsx. Proses K-means selanjutnya adalah menentukan jumlah cluster, menentukan titik awal dari setiap cluster sampai jarak terdekat data pada cluster yang sudah dibentuk. Berikut langkah-langkah yang dilakukan:

1. Menentukan jumlah cluster yang diinginkan oleh user (Biro Promosi). Dalam penelitian ini data yang ada dikelompokkan menjadi empat cluster.

2. Menentukan titik pusat awal (Centroid awal) dari setiap cluster. Dalam penelitian ini titik pusat awal (Centroid awal) ditentukkan oleh user (Biro Promosi) dengan cara memilih data mahasiswa yang akan dijadikan sebagai titik pusat awal seperti yang terlihat pada Gambar 4:

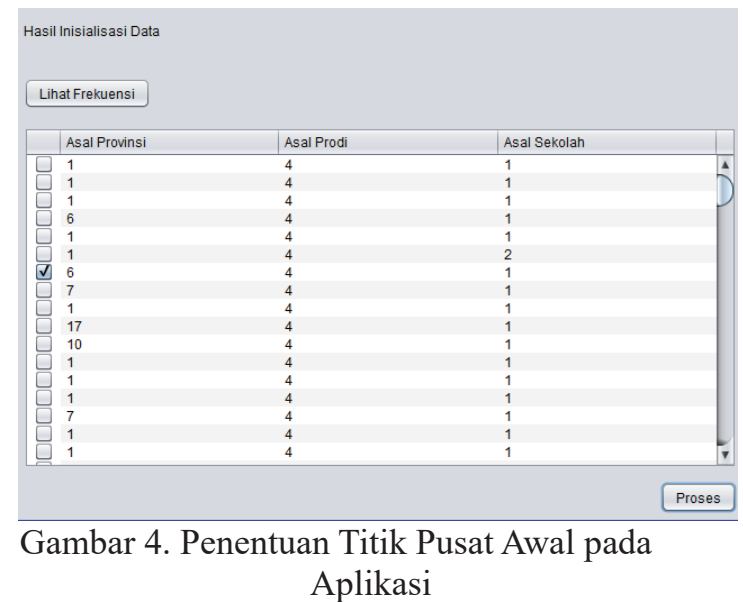

Gambar 4 merupakan merupakan penentuan inisialisasi titik pusat yang ditentukan random oleh user. Selanjutnya, 
akan ditunjukan di tabel 5 empat titik pusat yang digunakan.

Tabel 5. Titik Pusat Awal

\begin{tabular}{|c|c|c|c|}
\hline $\begin{array}{c}\text { Titik } \\
\text { Pusat } \\
\text { Awal }\end{array}$ & NIM & $\begin{array}{l}\text { Asal } \\
\text { Provinsi }\end{array}$ & Asal Prodi \\
\hline Cluster 1 & 602017007 & Lampung & Public Relation \\
\hline Cluster 2 & 672017008 & Jateng & $\begin{array}{l}\text { Teknik } \\
\text { Informatika }\end{array}$ \\
\hline Cluster 3 & 692017006 & Jatim & $\begin{array}{l}\text { Desain } \\
\text { Komunikasi } \\
\text { Visual }\end{array}$ \\
\hline Cluster 4 & 702017019 & NTT & $\begin{array}{l}\text { Pendidikan } \\
\text { Teknologi } \\
\text { Informasi dan } \\
\text { Komunikasi }\end{array}$ \\
\hline
\end{tabular}

3. Menempatkan setiap data pada cluster. Pada penelitian ini digunakan teori Euclidean untuk mengalokasikan setiap data pada cluster terdekat yang ditunjukkan pada Rumus 1.

$D(i, j)=$ $\sqrt{\left(X_{1 i}-X_{1 j}\right)^{2}+\left(X_{2 i}-X_{2 j}\right)^{2}+\ldots+\left(X_{k i}-X_{k j}\right)^{2}}$.

$\mathrm{D}(\mathrm{i}, \mathrm{j}) \quad=$ Jarak data ke $i$ ke pusat cluster $j$

$\mathrm{X}_{\mathrm{ki}} \quad=$ Data ke $i$ pada atribut data ke $k$

$\mathrm{X}_{\mathrm{kj}} \quad=$ Titik pusat ke $j$ pada atribut ke $k$

Rumus tersebut diimplementasikan pada data yang sudah ada, contohnya adalah sebagai berikut:

$$
\begin{aligned}
& D(1,1)=\sqrt{(2-6)^{2}+(7-4)^{2}+} \\
& D(1,2)=\sqrt{(2-1)^{2}+(7-1)^{2}+} \\
& D(1,3)=\sqrt{(2-13)^{2}+(7-3)^{2}+} \\
& D(1,4)=\sqrt{(2-2)^{2}+(7-6)^{2}+}
\end{aligned}
$$

$\mathrm{D}(1,1)$ menunjukatan data pertama yang di operasikan dengan titik pusat awal pertama. X1i, X2i dan Xki menjelaskan data setiap parameter yang ada yakni angka 2 data dari parameter Asal Provinsi, angka 7 adalah data dari parameter Asal Prodi dan angka 1 adalah data dari parameter Asal sekolah dimana data tersebut diambil dari data mahasiswa pada field pertama yang diimpor. Sedangkan X1j, X2j dan X3j menjelaskan data setiap parameter dari titik pusat awal pertama, yakni angka 2 dari parameter Asal Provinsi, angka 6 dari parameter Asal Prodi dan angka 3 dari Asal Sekolah.

Berdasarkan hasil keempat perhitungan tersebut data mahasiswa pertama dimasukkan kedalam cluster 4. Hasil perhitungan selengkapnya untuk beberapa data mahasiswa pertama dapat

\begin{tabular}{|c|c|c|c|c|c|c|}
\hline \multirow[t]{2}{*}{ No } & \multirow[t]{2}{*}{ NIM } & \multicolumn{4}{|c|}{ Jarak ke- } & \multirow{2}{*}{$\begin{array}{l}\text { Jarak } \\
\text { terdekat } \\
\text { ke cluster }\end{array}$} \\
\hline & & $\mathrm{C} 1$ & $\mathrm{C} 2$ & C3 & $\mathrm{C} 4$ & \\
\hline 1 & 732017002 & 5,66 & 6,16 & 11,75 & 2,24 & 4 \\
\hline 2 & 672017294 & 5,83 & 1 & 12,69 & 5,48 & 2 \\
\hline 3 & 682017072 & 5,74 & 1,41 & 12,08 & 3,16 & 2 \\
\hline 4 & 682017088 & 5,39 & 1,41 & 12,08 & 4,58 & 2 \\
\hline 5 & 682017028 & 4,58 & 9,06 & 5,09 & 9 & 3 \\
\hline
\end{tabular}
dilihat pada Tabel 6 .

Tabel 6. Hasil Perhitungan Jarak Setiap Data ke Setiap Cluster

Setelah semua data sudah ditempatkan kedalam cluster terdekat, hitung kembali pusat cluster yang baru berdasarkan rata-rata anggota yang ada pada cluster tersebut.

5. Setelah mendapatkan pusat cluster baru, lakukan kembali langkah ketiga

6. Dan, seterusnya sampai titik pusat dari setiap cluster tidak berubah lagi dan tidak ada data yang berpindah cluster.

Dalam penelitian ini, iterasi clustering data terjadi sebanyak 5 kali iterasi. Pada iterasi ke- 5 ini, titik pusat dari setiap cluster sudah tidak berubah dan tidak ada lagi data yang berpindah dari satu cluster ke cluster yang lain sehingga proses iterasi berakhir. Seperti yang ditunjukkan oleh Tabel 7.

Tabel 7. Jumlah Iterasi yang Terjadi

\begin{tabular}{lcccc}
\hline Iterasi & \multicolumn{4}{c}{ Perubahan pada cluster } \\
& $\mathbf{1}$ & $\mathbf{2}$ & $\mathbf{3}$ & $\mathbf{4}$ \\
\hline 1 & 1,902 & 0,884 & 2,456 & 2,010 \\
2 & 0,472 & 0,000 & 0,896 & 0,110 \\
3 & 0,499 & 0,033 & 0,824 & 0,000 \\
4 & 0,357 & 0,000 & 0,843 & 0,000 \\
5 & 0,000 & 0,000 & 0,000 & 0,000 \\
\hline
\end{tabular}

Berdasarkan hasil pengelompokkan data menggunakan metode K-Means Clustering didapatkan hasil clustering hingga iterasi ke- 5. Hasil dari clustering tersebut dapat dilihat pada Tabel 8 .

Tabel 8. Hasil Analisis K-Means Clustering 


\begin{tabular}{|c|c|c|c|}
\hline Cluster & Asal Provinsi & Asal Prodi & Asal Sekolah \\
\hline Cluster 1 & $\begin{array}{l}\text { Sulut }=20 \text { mahasiswa } \\
\text { Lampung = } 19 \text { mahasiswa } \\
\text { Jabar }=17 \text { mahasiswa } \\
\text { Sulsel = } 14 \text { mahasiswa } \\
\text { Kalbar = } 13 \text { mahasiswa } \\
\text { Kalteng = } 11 \text { mahasiswa } \\
\text { Sumut = } 10 \text { mahasiswa } \\
\text { Papua Barat = } 9 \text { mahasiswa } \\
\text { Total } 113 \text { Mahasiswa }\end{array}$ & $\begin{array}{l}\mathrm{TI}=56 \text { mahasiswa } \\
\mathrm{SI}=25 \text { mahasiswa } \\
\mathrm{DKV}=14 \text { mahasiswa } \\
\mathrm{PR}=9 \text { mahasiswa } \\
\mathrm{DesPar}=8 \text { mahasiswa } \\
\mathrm{IP}=1 \text { mahasiswa }\end{array}$ & $\begin{array}{l}\text { SMA }=98 \text { mahasiswa } \\
\text { SLTA Lain }=8 \text { mahasiswa } \\
\text { SMK/STM }=7 \text { mahasiswa }\end{array}$ \\
\hline Cluster 2 & $\begin{array}{l}\text { Jateng }=271 \text { mahasiswa } \\
\text { NTT }=23 \text { mahasiswa } \\
\text { Papua }=22 \text { mahasiswa } \\
\text { Maluku }=19 \text { mahasiswa } \\
\text { Total } 335 \text { Mahasiwa }\end{array}$ & $\begin{array}{l}\mathrm{TI}=205 \text { mahasiswa } \\
\mathrm{SI}=81 \text { mahasiswa } \\
\mathrm{DKV}=49 \text { mahasiswa }\end{array}$ & $\begin{array}{l}\mathrm{SMA}=224 \text { mahasiswa } \\
\mathrm{SMK} / \mathrm{STM}=97 \text { mahasiswa } \\
\text { SLTA Lain }=14 \text { mahasiswa }\end{array}$ \\
\hline Cluster 3 & $\begin{array}{l}\text { Jatim }=7 \text { mahasiswa } \\
\text { Banten }=7 \text { mahasiswa } \\
\text { Sulteng }=6 \text { mahasiswa } \\
\text { DKI Jakarta }=5 \text { mahasiswa } \\
\text { Sumsel }=5 \text { mahasiswa } \\
\mathrm{N} / \mathrm{A}=4 \text { mahasiswa } \\
\text { Maluku Utara }=4 \text { mahasiswa } \\
\text { DIY = } 3 \text { mahasiswa } \\
\text { Sultenggara = } 2 \text { mahasiswa } \\
\text { Kaltim = } 2 \text { mahasiswa } \\
\text { Bali = } 1 \text { mahasiswa } \\
\text { Kalmut = } 1 \text { mahasiswa } \\
\text { Kalut }=1 \text { mahasiswa } \\
\text { Riau }=1 \text { mahasiswa } \\
\text { Bengkulu = } 1 \text { mahasiswa } \\
\text { Jambi = } 1 \text { mahasiswa } \\
\text { Bangka belitung }=1 \text { mahasiswa } \\
\text { Total } 52 \text { Mahasiswa }\end{array}$ & $\begin{array}{l}\mathrm{TI}=28 \text { mahasiswa } \\
\mathrm{SI}=9 \text { mahasiswa } \\
\mathrm{DKV}=9 \text { mahasiswa } \\
\mathrm{PR}=3 \text { mahasiswa } \\
\text { DesPar }=2 \text { mahasiswa } \\
\mathrm{PTIK}=1 \text { mahasiswa }\end{array}$ & $\begin{array}{l}\text { SMA }=36 \text { mahasiswa } \\
\text { SMK/STM }=8 \text { mahasiswa } \\
\text { SLTA Lain }=6 \text { Mahasiswa } \\
\text { N/A }=2\end{array}$ \\
\hline Cluster 4 & $\begin{array}{l}\text { Jateng }=40 \text { mahasiswa } \\
\text { NTT }=10 \text { mahasiswa } \\
\text { Maluku }=2 \text { mahasiswa } \\
\text { Papua }=1 \text { mahasiswa } \\
\text { Total } 53 \text { Mahasiswa }\end{array}$ & $\begin{array}{l}\mathrm{PTIK}=20 \text { mahasiswa } \\
\mathrm{PR}=17 \text { mahasiswa } \\
\text { DesPar }=13 \text { mahasiswa } \\
\mathrm{IP}=3 \text { mahasiswa }\end{array}$ & $\begin{array}{l}\mathrm{SMA}=39 \text { mahasiswa } \\
\mathrm{SMK} / \mathrm{STM}=10 \text { mahasiswa } \\
\text { SLTA Lain }=4 \text { mahasiswa }\end{array}$ \\
\hline
\end{tabular}

Berikut adalah output hasil perhitungan menggunakan algoritma $K$ Means pada aplikasi.

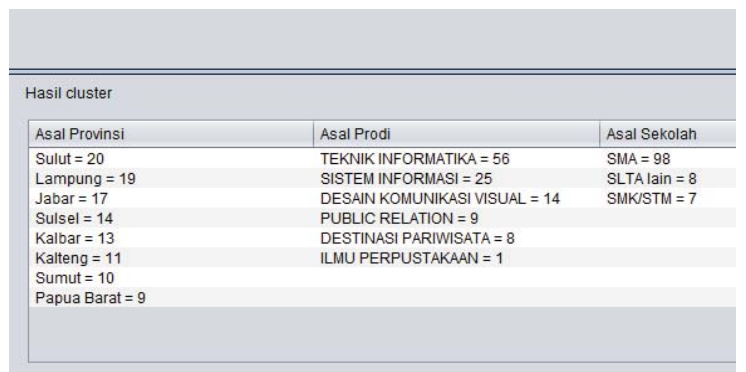

Gambar 5. Hasil Akhir Cluster 1

Dilakukan pengujian proses clustering sebanyak empat cluster. Pada Gambar 5 dapat dilihat bahwa cluster satu didominasi oleh mahasiswa yang berasal provinsi dari Sulawesi Utara dan Lampung yakni 20 mahasiswa dan 19 mahasiswa. Sedangkan berdasarkan minat program studi adalah Teknik Informatika yakni 56 mahasiswa dan Sistem Informasi yang berjumlah 25 mahasiswa. Yang dimana rata-rata mahasiswa berasal dari SMA. Cluster ke-dua didominasi oleh Jawa Tengah yakni 271 mahasiswa dan minat program studi Teknik Informatika yang berjumlah 205 mahasiswa dan rata-rata mahasiswa masih berasal dari SMA. Selanjutnya, Cluster ke-tiga didominasi oleh Jawa Timur dan Banten yang memiliki jumlah yang sama yakni 7 mahasiswa, yang minat program studinya masih dari Teknik Informatika dan Sistem Informasi dan lulusan dari SMA. Terakhir, cluster keempat didominasi oleh Jawa Tengah dengan jumlah mahasiswa 40 mahasiswa dan Nusa Tenggara Timur yang berjumlah 10 mahasiswa. Yang dimana memiliki minat program studi Pendidikan Teknologi Infomasi dan Komunikasi yang berjumlah 20 mahasiswa dan Public Relation 17 mahasiswa yang rata-rata mahasiswa lulusan dari SMA.

Proses perhitungan menggunakan $K$ Means juga dilakukan melalui aplikasi lain 
yakni IBM SPSS menggunakan data yang sama yaitu data mahasiswa tahun 2017. Hasil dari SPSS digunakan untuk membandingkan hasil perhitungan yang didapatkan dari aplikasi yang dibangun sesuai dengan hasil dari SPSS atau tidak. Hasil yang didapat dari perhitungan melalui SPSS sama dengan hasil yang didapat pada proses perhitungan melalui aplikasi yang dibangun pada penelitian ini. Proses iterasi yang didapat dari SPSS yakni 5 iterasi, dapat dilihat pada Gambar 6.

Iteration History ${ }^{a}$

\begin{tabular}{|l|r|r|r|r|}
\hline \multirow{2}{*}{ Iteration } & \multicolumn{4}{|c|}{ Change in Cluster Centers } \\
\cline { 2 - 5 } & 1 & \multicolumn{1}{|c|}{2} & \multicolumn{1}{c|}{3} \\
\hline 1 & 1,902 &, 884 & 2,456 & 2,010 \\
2 &, 472 &, 000 &, 896 &, 110 \\
3 &, 499 &, 033 &, 824 &, 000 \\
4 &, 357 &, 000 &, 843 &, 000 \\
5 &, 000 &, 000 &, 000 &, 000 \\
\hline
\end{tabular}

a. Convergence achieved due to no or small change in cluster centers. The maximum absolute coordinate change for any center is, 000 . The current iteration is 5 . The minimum distance between initial centers is

4,899

\section{Gambar 6. Proses Iterasi Pengujian SPSS}

Gambar 6 adalah proses iterasi yang dilakukan melalui SPSS, sedangkan proses iterasi yang terjadi pada aplikasi terlihat pada Tabel 7. Dari kedua gambar tersebut dapat disimpulkan bahwa proses iterasi pada SPSS sama dengan proses iterasi pada aplikasi. Adapun jumlah data mahasiswa yang dianalisa menggunakan aplikasi dan SPSS menghasilkan data yang sesuai seperti yang ditunjukkan pada Tabel 7, dimana cluster 1 memiliki 113 mahasiswa, cluster 2 memiliki 335 mahasiswa, cluster 3 memiliki 52 mahasiswa dan cluster 4 memiliki 53 mahasiswa. Jumlah mahasiswa untuk setiap cluster pada perhitungan $K$ Means yang dilakukan pada SPSS terlihat pada Gambar 6.

Number of Cases in each
Cluster
\begin{tabular}{|ll|r|}
\hline Cluster & 1 & 113,000 \\
& 2 & 335,000 \\
& 3 & 52,000 \\
& 4 & 53,000 \\
Valid & & 553,000 \\
Missing & &, 000 \\
\hline
\end{tabular}

Gambar 7. Hasil Jumlah Data Setiap Cluster

Hasil titik pusat akhir yang didapat dari perbandingan menggunakan SPSS sesuai dengan yang dianalisa pada Gambar 8 hanya saja SPSS menggunakan pembulatan, dapat dilihat pada Gambar 8 .

Final Cluster Centers

\begin{tabular}{|l|r|r|r|r|}
\hline \multirow{2}{*}{} & \multicolumn{5}{|c|}{ Cluster } \\
\cline { 2 - 5 } & 1 & 2 & 3 & \multicolumn{1}{|c|}{4} \\
\hline V2 & 8 & 1 & 18 & 1 \\
V3 & 2 & 2 & 2 & 5 \\
V4 & 1 & 1 & 2 & 1 \\
\hline
\end{tabular}

Gambar 8. Titik Pusat Akhir Menggunakan SPSS

Pengujian hasil perhitungan K-Means juga dilakukan dengan membandingkan hasil pengelompokan data mahasiswa secara manual sesuai atau tidak dengan hasil perhitungan menggunakan aplikasi yang dibangun. Pada proses pengelompokan secara manual, data mahasiswa berdasarkan asal provinsi diambil secara acak, kemudian dihitung jumlah mahasiswa untuk setiap prodi dan asal sekolah. Hasil pengelompokan secara manual terlihat pada Tabel 9. 
Tabel 9. Hasil Perhitungan Manual

\begin{tabular}{|c|c|c|c|}
\hline Cluster & Asal Provinsi & Asal Prodi & Asal Sekolah \\
\hline 1 & $\begin{array}{l}\text { Sulut }=20 \text { mahasiswa } \\
\text { Lampung = } 19 \text { mahasiswa } \\
\text { Jabar }=17 \text { mahasiswa } \\
\text { Sulsel }=14 \text { mahasiswa } \\
\text { Kalbar }=13 \text { mahasiswa } \\
\text { Kalteng }=11 \text { mahasiswa } \\
\text { Sumut }=10 \text { mahasiswa } \\
\text { Papua Barat }=9 \text { mahasiswa } \\
\text { Total 113 Mahasiswa }\end{array}$ & $\begin{array}{l}\text { TI }=56 \text { mahasiswa } \\
\mathrm{SI}=25 \text { mahasiswa } \\
\mathrm{DKV}=14 \text { mahasiswa } \\
\mathrm{PR}=9 \text { mahasiswa } \\
\text { DesPar = } 8 \text { mahasiswa } \\
\mathrm{IP}=1 \text { mahasiswa }\end{array}$ & $\begin{array}{l}\text { SMA }=98 \text { mahasiswa } \\
\text { SLTA Lain }=8 \text { mahasiswa } \\
\text { SMK/STM }=7 \text { mahasiswa }\end{array}$ \\
\hline 2 & $\begin{array}{l}\text { Jateng }=271 \text { mahasiswa } \\
\text { NTT }=23 \text { mahasiswa } \\
\text { Papua }=22 \text { mahasiswa } \\
\text { Maluku }=19 \text { mahasiswa } \\
\text { Total } 335 \text { Mahasiswa }\end{array}$ & $\begin{array}{l}\mathrm{TI}=205 \text { mahasiswa } \\
\mathrm{SI}=81 \text { mahasiswa } \\
\mathrm{DKV}=32 \text { mahasiswa } \\
\mathrm{PR}=17 \text { mahasiswa }\end{array}$ & $\begin{array}{l}\text { SMA }=229 \text { mahasiswa } \\
\text { SMK/STM }=91 \\
\text { mahasiswa } \\
\text { SLTA Lain }=15 \\
\text { mahasiswa }\end{array}$ \\
\hline 3 & $\begin{array}{l}\text { Jatim }=7 \text { mahasiswa } \\
\text { Banten }=7 \text { mahasiswa } \\
\text { Sulteng }=6 \text { mahasiswa } \\
\text { DKI Jakarta }=5 \text { mahasiswa } \\
\text { Sumsel }=5 \text { mahasiswa } \\
\text { N } / \mathrm{A}=4 \text { mahasiswa } \\
\text { Maluku Utara }=4 \text { mahasiswa } \\
\text { DIY }=3 \text { mahasiswa } \\
\text { Sultenggara }=2 \text { mahasiswa } \\
\text { Kaltim }=2 \text { mahasiswa } \\
\text { Bali }=1 \text { mahasiswa } \\
\text { Kalmut }=1 \text { mahasiswa } \\
\text { Kalut }=1 \text { mahasiswa } \\
\text { Riau }=1 \text { mahasiswa } \\
\text { Bengkulu }=1 \text { mahasiswa } \\
\text { Jambi }=1 \text { mahasiswa } \\
\text { Bangka belitung }=1 \text { mahasiswa } \\
\text { Total } 52 \text { Mahasiswa }\end{array}$ & $\begin{array}{l}\text { TI }=28 \text { mahasiswa } \\
\mathrm{SI}=9 \text { mahasiswa } \\
\mathrm{DKV}=9 \text { mahasiswa } \\
\mathrm{PR}=3 \text { mahasiswa } \\
\text { DesPar }=2 \text { mahasiswa } \\
\text { PTIK = } 1 \text { mahasiswa }\end{array}$ & $\begin{array}{l}\text { SMA }=36 \text { mahasiswa } \\
\text { SMK/STM }=8 \text { mahasiswa } \\
\text { SLTA Lain = } 6 \text { Mahasiswa } \\
\text { N/A = } 2\end{array}$ \\
\hline 4 & $\begin{array}{l}\text { Jateng }=40 \text { Mahasiswa } \\
\text { NTT }=10 \text { mahasiswa } \\
\text { Maluku }=2 \text { mahasiswa } \\
\text { Papua }=1 \text { mahasiswa } \\
\text { Total } 53 \text { Mahasiswa }\end{array}$ & $\begin{array}{l}\mathrm{TI}=36 \text { mahasiswa } \\
\mathrm{PR}=17 \text { Mahasiswa }\end{array}$ & $\begin{array}{l}\text { SMA }=47 \text { Mahasiswa } \\
\text { SMK/STM }=5 \text { mahasiswa } \\
\text { SLTA Lain }=1 \text { mahasiswa }\end{array}$ \\
\hline
\end{tabular}

Dari Tabel 9 dan Tabel 8, terlihat bahwa pada cluster 1 data yang dihasilkan sama dimana Sulut mempunyai 20 mahasiswa, lampung mempunyai 19 mahasiswa dimana prodi yang diminati adalah Teknik Informatika dan Sistem Informasi rata-rata berasal dari SMA. Pada cluster 2 hasil perhitungan K-Means pada aplikasi memiliki beberapa perbedaan yang tidak terlalu jauh dengan pengelompokan secara manual yaitu pada pengelompokan manual jumlah mahasiswa DKV adalah 32 orang sedangkan pengelompokan menggunakan aplikasi jumlah mahasiswa DKV adalah 49, serta prodi PR yang muncul pada pengelompokan secara manual dan tidak ada pada pengelompokan pada aplikasi. Pada cluster 3 pengelompokan data dari hasil perhitungan K-Means pada aplikasi dan secara manual sesuai. Pada cluster 4 pengelompokan data dari hasil perhitungan K-Means pada aplikasi dan secara manual memiliki perbedaan yakni prodi IP memiliki 3 mahasiswa sedangkan pada aplikasi tidak ada prodi IP. Hasil yang didapatkan secara manual terlihat pada Tabel 9 .

Pengelompokan data terbentuk empat cluster yaitu, cluster satu yang berjumlah 113 mahasiswa dengan rata-rata mahasiswa berasal dari SMA memiliki minat program studi Teknik Informatika dan Sistem Informasi, cluster dua yang berjumlah 335 mahasiswa dengan rata-rata mahasiswa berasal dari SMA memiliki minat program studi Teknik Informatika dan Sistem Informasi, cluster tiga yang berjumlah 52 mahasiswa dimana rata-rata mahasiswa berasal dari SMA dan memiliki minat program studi yang sama dengan cluster satu dan dua yakni Teknik Informatika dan Sistem Informasi, dan cluster empat berjumlah 53 mahasiswa yang rata-rata mahasiswa berasal dari SMA memiliki 
minat program studi Pendidikan Teknologi Informasi dan Komputer serta Public Relation.

\section{KESIMPULAN DAN SARAN}

\section{Kesimpulan}

Berdasarkan penelitian yang dilakukan maka dapat disimpulkan bahwa analisa data mahasiswa menggunakan Algoritma K-Means Clustering menghasilkan pengelompokan data mahasiswa berdasarkan asal provinsi, prodi dan asal sekolah. Pemilihan titik centroid awal dipilih oleh user agar dapat melihat titik awal yang dipilih.

Berdasarkan pengujian terhadap hasil perhitungan K-Means secara aplikasi didapat tidak jauh berbeda dengan perhitungan secara manual. Dimana perbedaan yang ada hanya pada cluster 2 yang memiki jumlah mahasiswa DKV yang berbeda serta prodi PR yang masuk pada cluster 2 dan prodi IP pada cluster 4 pada saat pengujian secara manual.

Dari hasil pengelompokan menggunakan K-Means, Biro Promosi dapat melihat asal daerah yang memiliki jumlah mahasiswa yang besar pada suatu prodi serta asal sekolah mahasiswa yang dominan pada suatu prodi. Seperti pada cluster 1, provinsi Sulawesi Utara dan Lampung mempunyai mahasiswa yang banyak di program studi Teknik Informatika dan Sistem Informasi. Informasi tersebut dapat digunakan Biro Promosi sebagai dasar dari pelaksanaan promosi.

\section{Saran}

Berdasarkan hasil penulisan yang telah dilakukan maka diharapkan penulisan selanjutnya untuk menguji dengan algoritma clustering lainnya seperti Fuzzy C-Means atau metode algoritma yang lain, serta aplikasi yang dibangun bisa dikembangkan lagi menjadi lebih user friendly.
Agusta, Y., 2007. K-Means - Penerapan, Permasalahan dan Metode Terkait: Jurusan Informatika, Fakultas Sistem dan Informatika, STMIK STIKOM Bali.

Larose, D., 2005. Discovering Knowledge In Data: An Introduction to Data Mining. Kota: Haboken, New Jersey, Penerbit: A John Wiley \& Sons, inc., Publication.

Ong, J. O., 2013. Implementasi Algoritma K-Means Clustering untuk Menentukan Strategi Marketing President University, Jurnal Ilmiah Teknik Industri: Jurusan Teknik Industri, Fakultas Teknik, President University.

Ramadhani, R. D., 2013. Data Mining Menggunakan Algoritma K-Means Clustering untuk Menentukan Strategi Promosi Universitas Dian Nuswantoro: Jurusan Sistem Informasi, Fakultas Ilmu Komputer, Universitas Dian Nuswantoro.

Santosa, B., 2007. Data Mining Terapan dengan MATLAB. Kota: Yogyakarta, Penerbit: Graha Ilmu.

\section{DAFTAR PUSTAKA}

